\title{
The Diagnosis AND ImProvement OF FinanCial Literacy Among Young PEOPLe
}

\author{
Justyna Kurczewska ${ }^{1}$; Malgorzata Solarz ${ }^{2}$ \\ Wrocław University of Economics, Faculty of Economics, Management and Tourism, \\ Department of Finance and Accounting, Nowowiejska 3, 58-500, Jelenia Góra, Polska \\ e-mail: ${ }^{1}$ justynka2603@ interia.eu; ${ }^{2}$ malgorzata.solarz@ue.wroc.pl
}

\begin{abstract}
Presenting financial knowledge and skills remains the condition for proper management of personal finance in a household and protects against financial exclusion. The purpose of this article is to diagnose the level of financial literacy among young people and to present the selected educational activities addressed to young Poles, which are supposed to improve their financial knowledge and skills. The review of the existing research and the results of the conducted survey confirm that financial literacy of young people in the Lower Silesia region is insufficient. Polish financial institutions perceive the need for implementing various mechanisms to upgrade the financial awareness among young people, however, the scale of carried out educational activities is far too small against the existing needs as well as characterized by randomness.
\end{abstract}

\section{Introduction}

The problems of consumer awareness gained significance in the face of ongoing economic downturn, the increasing inequality and highly complicated financial products used in everyday life. In the opinion of Cate Lyons-Crew (Financial Inclusion Program Manager) "Financial literacy remains indispensable in order to function in a modern society and becomes increasingly important in a long-term perspective of an individual and the entire society decent existence." [15, p. 13]

In recent years the low level of financial literacy has become the subject matter of heated international debates, as well as recommendations and guidelines issued by the European Commission, OECD and the World Bank, and primarily has become the component of national development strategies in many countries all over the world. The last financial crisis, experienced at the turn of 2007/2008, revealed a very high level of financial illiteracy in most societies worldwide (OECD 2005 [22], 2009 [21]; The World Bank 2014 [33]; European Commission 2008 [25]). Furthermore, this crisis illustrated that the individuals presenting low level of financial literacy are very vulnerable to manipulation by both the official banking and shadow banking institutions, and also remain more often susceptible to bankruptcy and, in consequence, to poverty, therefore it seems founded to implement all sorts of mechanisms aimed at financial literacy improvement.

The purpose of this article is to diagnose the level of financial literacy among young people and to present the selected educational activities addressed to young Poles, which are supposed to improve their financial knowledge and skills. Financial education offers consumers the possibility for correct identification of opportunities and threats generated by the market of banking services. The method of subject literature analysis, including the reports issued by financial institutions, was used in order to meet the defined objective. Moreover, the selected results of the existing research in this area were presented, as well as the author's own survey addressed to a group of young people from the Lower Silesia region. 
Financial literacy, financial capability and financial education - mutual relations

In order to meet the increasingly demanding market conditions and make both complex and difficult financial decisions, households have to present an adequate level of financial literacy. Foreign literature references discussing the problem offer several definitions of this concept. These definitions tend to emphasize the objective knowledge on specific topics related to money, economics, or financial matters, and also the subjective measures of selfreported confidence [27, p. 4]. In other words, financial literacy refers to the combination of skills and knowledge which facilitate undertaking well thought over and effective decisions by an individual and influencing his/her financial situation. The concept of financial literacy is frequently used as synonymous to financial capability, however, the latter has a broader meaning. Financial capability is an extensive concept, encompassing people's knowledge and skills necessary to understand their own financial circumstances, along with the motivation to take action. Financially capable consumers plan ahead, find and use information, know when to seek advice and can understand and act on this advice, leading to greater participation in the financial services market [13, p. 19]. By contrast, financial capability is generally understood to be a concept with three different components: financial knowledge and understanding, financial skills and competence, and financial responsibility [27, p. 4]:

1. Financial knowledge and understanding: The ability to make sense of and manipulate money in its different forms, uses, and functions, including the ability to deal with everyday financial matters and make the right choices for one's own needs.

2. Financial skills and competence: The ability to apply knowledge and understanding across a range of contexts including both predictable and unexpected situations and also including the ability to manage and resolve any financial problems or opportunities.

3. Financial responsibility: The ability to appreciate the wider impact of financial decisions on personal circumstances, the family, and the broader community, and to understand rights, responsibilities, and sources of advice or guidance.

Presenting adequate level of financial literacy constitutes an indispensable condition for proper management of personal and household finance, since it allows obtaining and maintaining financial stability. The results of conducted research confirm that the individuals with more extensive knowledge and better financial skills plan their future pension more efficiently, save larger financial means for this purpose, refrain from being tempted by selfcontrol, and thus ultimately guarantee their future financial security (for more see: Hastings and Mitchell 2011 [12]; Lusardi and Tufano 2009 [18]; Lusardi and Mitchell 2006 [16], 2013 [17]; van Rooij et al. 2012 [34]). On the contrary, the households presenting low financial literacy are more vulnerable to excessive debt problems which, in a longer-term perspective, can result in financial exclusion. This term can be defined as personal or household inability to take advantage of the necessary financial services, along with ensuring that they remain appropriately tailored to the reported needs. Financial exclusion became the subject of analysis conducted by the European Commission, which published a report in March 2008 stating that financial exclusion refers to the situation of problems occurring in both access and opportunities to use adequate financial products and services, and in consequence a consumer is deprived of a chance to lead a normal life in a society [5, p. 9]. Low level of financial literacy is listed in the above-mentioned document as one of the reasons underlying financial exclusion.

Due to vital importance of financial literacy for households, for the general public and also for economy, this category was studied with greater detail and became the subject matter of numerous research and discussions. The attempts to measure financial knowledge and skills 
of individuals were frequently undertaken, however, their results indicated clearly an insufficient level of financial literacy and confirmed the need for corrective measures in this area. For example, in 2005 the level of financial knowledge was diagnosed in an international scale by OECD. In accordance with its results, as many as 8 out of 10 people had an incorrect idea of interest rates or other credit costs, 5 out of 10 admitted they do not understand such financial products as mortgage, whereas 2 out of 10 were not able to provide correct answers to questions about inflation and interest rates on deposits [22, pp. 10-20]. The abovementioned organization coordinates the Programme for International Student Assessment, which aims at obtaining comparable data about the skills presented by students over 15 . It is supposed to result in an improved quality of teaching and educations systems organization. The diagnosed knowledge and skills cover e.g. such areas as mathematics, nature, and starting from 2012 also finance [24, p. 13].

The results of research carried out by A. Atkinson, F. A. Messy in a group of 14 countries, including Poland, Czech Republic, Germany, Great Britain, Ireland or Hungary reveal the shortcomings in both financial knowledge and skills of Polish consumers, since their responses were in several aspects worse than in the majority of developed European countries. Low percentage of correct indications was predominant in comprehending the undertaken risk and risk-return relationship. Correct responses were given by only $48 \%$ of Polish respondents, while the respective number in other surveyed countries were as follows: Czech Republic $81 \%$, Germany $-79 \%$, Great Britain $77 \%$, Hungary $-86 \%$ [1].

Complex research on the level of financial literacy is also conducted in Poland, e.g. the report by Kronenberg Foundation at Citi Handlowy bank from 2009 [28]. Low level of financial knowledge in the group of poorest households [7, p. 9] was also confirmed by the research performed by the Microfinance Centre organization within the framework of "Financial Literacy for The Poor" project [20, pp. 36-37]. Moreover, Professor M. Iwanicz-Drozdowska and her team from Warsaw School of Economics were diagnosing financial literacy in the cross-section of occupational groups, e.g. among computer specialists, physicians, students and teenagers from upper-secondary schools [15, pp. 143-257]. Similar results were collected by B. Majewski, who was diagnosing financial literacy among students in primary and lowersecondary schools, and also observed an insufficient level of economic knowledge presented by this group [19, pp. 22-27].

In view of an unsatisfactory public level of financial literacy and having considered the continuously changing market of banking services, financial education should play an important role in any consumer's everyday life. This type of education is responsible for our financial knowledge and skills, which allow moving from financial literacy to financial capability. The discussion of selected financial education definitions is presented in Tab. 1.

In general terms financial education increases financial awareness in several crucial areas. It facilitates proper income management, influences the development of saving cultures, determines investment habits, emphasizes the importance of financial planning and allows making comparisons of financial product offers in order to make most suitable choices tailored to individual needs. 
Tab. 1: The discussion of selected financial education definitions

\begin{tabular}{|l|l|}
\hline Definition of financial education & Author (year) \\
\hline $\begin{array}{l}\text { Financial education is the process by which financial } \\
\text { consumers/investors improve their understanding of financial } \\
\text { products and concepts and, through information instruction and/or } \\
\text { objective advice, develop the skills and confidence to become more } \\
\text { aware of financial risks and opportunities, to make informed } \\
\text { Economices, to know where to go for help, and to take other effective } \\
\text { operation and } \\
\text { actions to improve their financial well-being }\end{array}$ & \\
\hline $\begin{array}{l}\text { the ability to make informed judgments and to take effective } \\
\text { decisions regarding the use and management of money }\end{array}$ & $\begin{array}{l}\text { Australia and New } \\
\text { Zealand Banking } \\
\text { Group Limited } \\
\text { (2008) }\end{array}$ \\
\hline $\begin{array}{l}\text { A combination of awareness, knowledge, skill, attitude and } \\
\text { behaviour necessary to make sound financial decisions and } \\
\text { ultimately achieve individual financial wellbeing }\end{array}$ & $\begin{array}{l}\text { OECD International } \\
\text { Network on Financial } \\
\text { Education (2011) }\end{array}$ \\
\hline $\begin{array}{l}\text { "the capability of consumers and small business owners to } \\
\text { understand retail financial products with a view to making informed } \\
\text { financial decisions" }\end{array}$ & $\begin{array}{l}\text { Habschick M., Seidl } \\
\text { B., Evers J. (2007) }\end{array}$ \\
\hline
\end{tabular}

Source: $[2, p .4],[11, p .8],[14, p .3],[22, p .26]$

Financial education should not be perceived as a substantive good, but rather as a public one, whereas financial awareness should become a universal resource of human capital rather than a dedicated one (terms used by: Wilkin 2010) [37, pp. 429-434]. In order to achieve that, adequate activities focused on financial education should be conducted not only by the State, within the framework of school classes, but also by financial institutions. In the latter case they come down to the implementation of the corporate social responsibility (CSR) concept. The European Commission published Green Paper on CRS in 2011 where corporate social responsibility is defined as the concept following which enterprises voluntarily implement strategies incorporating public interest, environment protection, as well as relations with stakeholders [4, p. 6]. Therefore, social responsibility is manifested in business not only by meeting formal requirements resulting from legal and economic rules, but also in undertaking socially expected and desirable activities. While observing market active financial entities it is noticeable that more and more of them incorporate the CRS strategy in their business strategies. Among the initiatives they undertake there are also these focused on financial literacy.

Both OECD [22] and the European Commission [3, pp. 7-9] recommended good practices, which should be used in the process of financial education. The Commission specified eight guidelines which can turn out helpful for the institutions involved in promoting financial education, in the course of developing and implementing financial education programmes (Figure 1).

Poland is regarded as one of the most active Eastern European countries in terms of initiatives aimed at upgrading public financial awareness. The selected programmes are discussed in Chapter 3. 


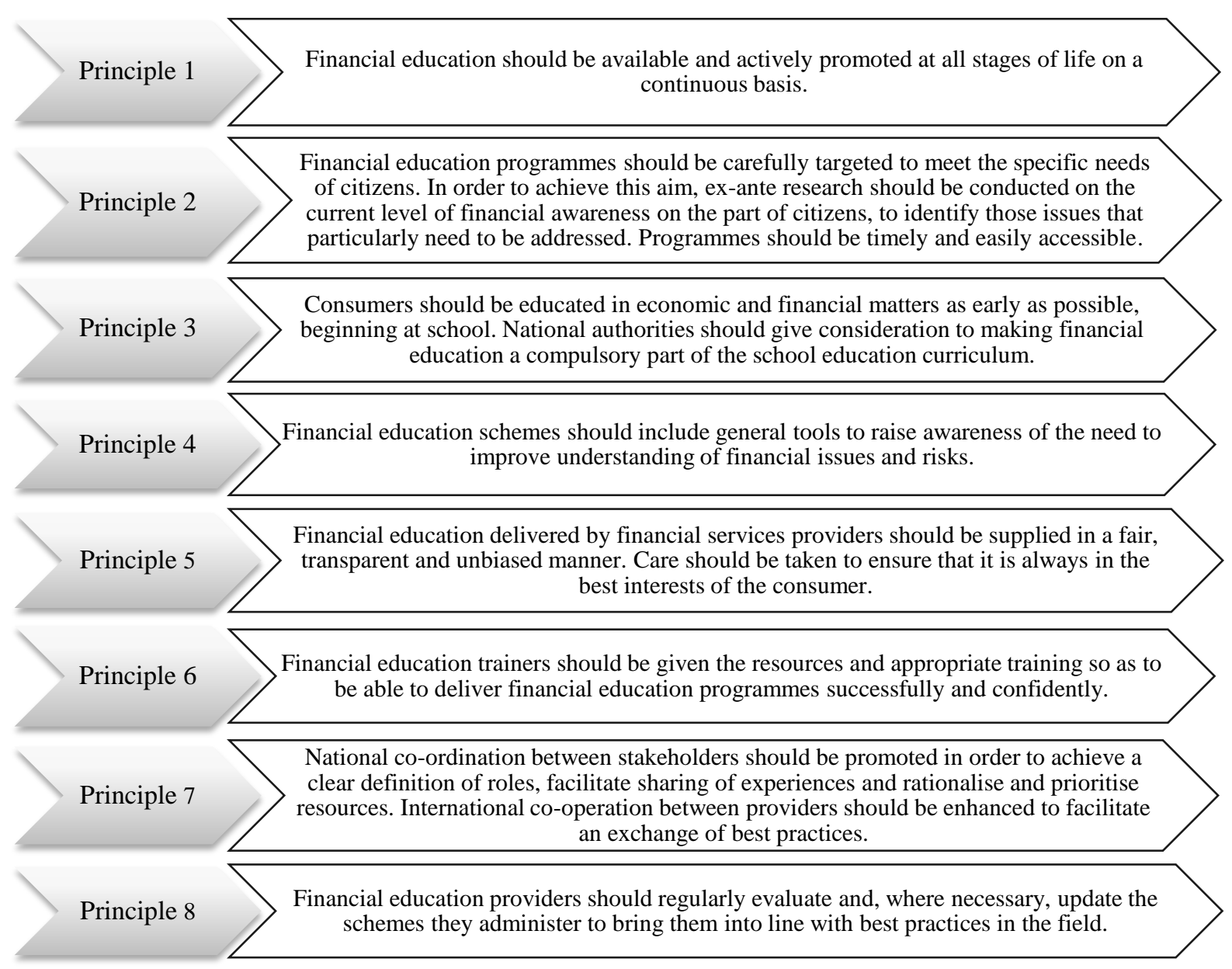

Source: [3, pp. 7-9]

\section{Fig. 1: Basic principles for the provision of high-quality financial education schemes}

\section{Financial literacy of young people in Lower Silesia in the light of the author's own research}

A survey was conducted in order to analyse the level of financial literacy among young people. The respondents aged 13-24 attended schools and universities in Lower Silesia. The survey covered 110 respondents: 18\% - lower-secondary school students, $27 \%$ - uppersecondary school students, and the remaining part of the surveyed group, i.e. $55 \%$ was made up of university students. Each person who took part in the survey had come across the basic financial terms taught during lessons at school in the course of particular education cycles.

The surveyed young people were asked to answer 13 questions related to financial issues, which allowed to define both subjective and objective level of the respondents' financial knowledge. Taking into account the respondents' structure by gender, the vast majority were females $-68 \%$, the remaining $32 \%$ were men. The conducted survey indicates that $52 \%$ of the respondents have a personal bank account. It should be emphasized that the highest percentage of persons who had a bank account was true for university students $-77 \%$ of the surveyed students. Among lower and upper-secondary school students this percentage was much lower and amounted to, respectively, 25\% and 20\% (for more see Figure 2). The young people covered by the survey were also asked whether they receive any pocket money from 
their parents on a regular basis, and if so, at what amount. The majority of respondents $-51 \%$ declined getting any pocket money from their parents. Among the remaining respondents young people receiving pocket money in the amount exceeding PLN 200 constituted the highest percentage.

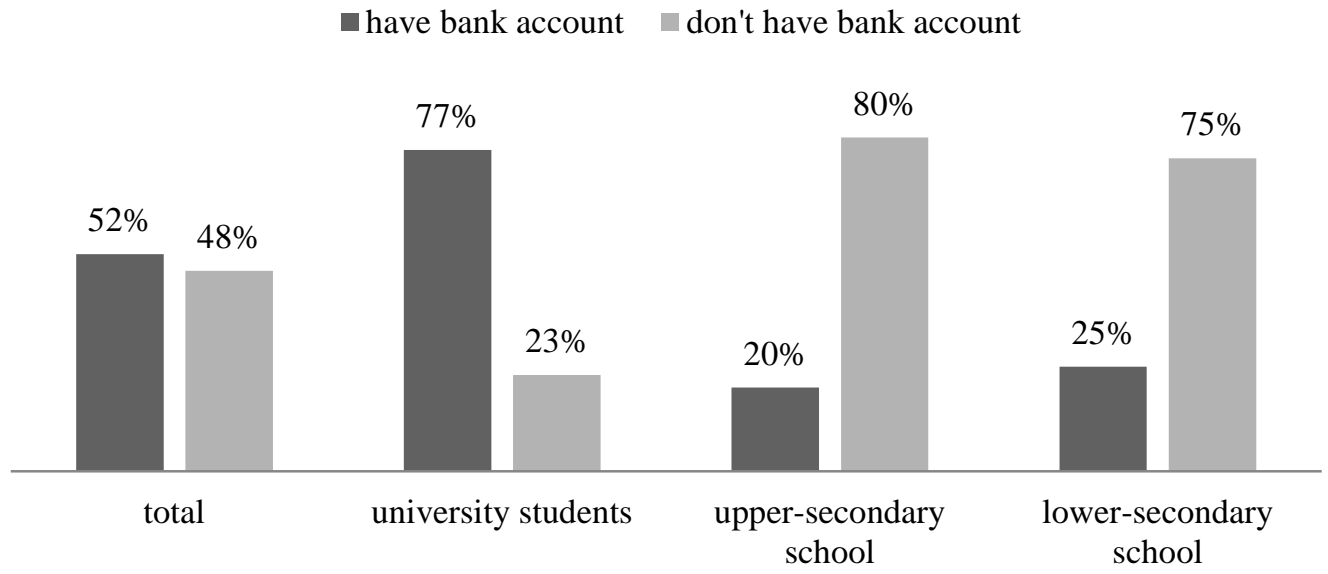

Source: Own

Fig. 2: Having a bank account among young people

In order to analyse their subjective level of financial knowledge young people were asked to answer the following question: "How do you evaluate your knowledge about the services offered by banks (e.g. personal bank accounts, deposits)?" The response to this question is illustrated in Figure 3.

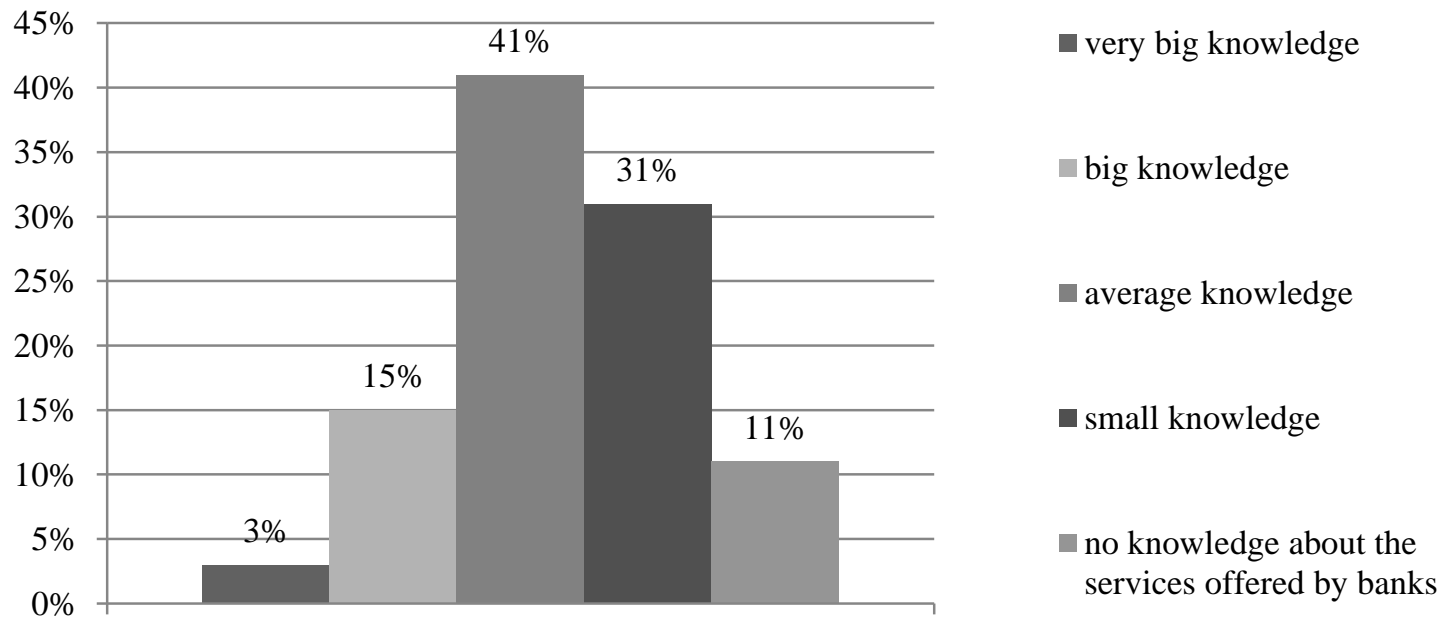

Source: Own

Fig. 3: Subjective level of financial literacy among the surveyed young people

The analysis of data presented in Figure 3 shows that the largest percentage of surveyed young people $-41 \%$ claim that their knowledge about services offered by banks is average, while $31 \%$ of respondents define their level of knowledge about financial services as low. As many as $11 \%$ of the surveyed revealed they do not present any knowledge at all about banking services.

Determining an objective level of financial literacy among young people required them to express their standpoint about 12 statements related to the functioning of a financial system. These statements, including the provided responses, are presented in Table 2. 
Tab. 2: The results of financial literacy survey among young people

\begin{tabular}{|c|c|c|c|c|c|}
\hline & \multirow{2}{*}{$\begin{array}{l}\text { Correct } \\
\text { answer }\end{array}$} & \multicolumn{3}{|c|}{$\begin{array}{l}\text { Responses provided by } \\
\text { young people }\end{array}$} \\
\hline \multicolumn{2}{|c|}{ Statement } & & TRUE & $\begin{array}{l}\text { NOT } \\
\text { TRUE }\end{array}$ & $\begin{array}{l}\text { DON'T } \\
\text { KNOW }\end{array}$ \\
\hline 1 & $\begin{array}{l}\text { A person without permanent income cannot } \\
\text { open a bank account }\end{array}$ & $\begin{array}{l}\text { NOT } \\
\text { TRUE }\end{array}$ & $9 \%$ & $85 \%$ & $6 \%$ \\
\hline 2 & $\begin{array}{l}\text { Each bank charges a fee for running a bank } \\
\text { account }\end{array}$ & $\begin{array}{l}\text { NOT } \\
\text { TRUE }\end{array}$ & $37 \%$ & $56 \%$ & $7 \%$ \\
\hline 3 & A person over 13 can open a bank account & TRUE & $81 \%$ & $7 \%$ & $12 \%$ \\
\hline 4 & $\begin{array}{l}\text { A person who has access to online personal } \\
\text { banking service can pay the bills (e.g. a } \\
\text { phone bill) using a personal computer }\end{array}$ & TRUE & $98 \%$ & $0 \%$ & $2 \%$ \\
\hline 5 & $\begin{array}{l}\text { A bank always charges a fee for cash } \\
\text { withdrawal in an ATM }\end{array}$ & $\begin{array}{l}\text { NOT } \\
\text { TRUE }\end{array}$ & $11 \%$ & $74 \%$ & $15 \%$ \\
\hline 6 & $\begin{array}{l}\text { Having a credit card is equivalent to being } \\
\text { granted a credit limit by a bank }\end{array}$ & TRUE & $52 \%$ & $25 \%$ & $24 \%$ \\
\hline 7 & A credit can be taken only in a bank & TRUE & $20 \%$ & $75 \%$ & $5 \%$ \\
\hline 8 & $\begin{array}{l}\text { Every adult holding all civic rights remains } \\
\text { a creditworthy individual }\end{array}$ & $\begin{array}{l}\text { NOT } \\
\text { TRUE }\end{array}$ & $29 \%$ & $59 \%$ & $12 \%$ \\
\hline 9 & $\begin{array}{l}\text { The level of interest rates on deposits and } \\
\text { bank credits is influenced by interest rate } \\
\text { changes announced by the central bank }\end{array}$ & TRUE & $55 \%$ & $10 \%$ & $35 \%$ \\
\hline 10 & $\begin{array}{l}\text { Kowalski who set up a deposit of PLN } \\
50000 \text { can lose the entire amount if his } \\
\text { bank declares bankruptcy }\end{array}$ & $\begin{array}{l}\text { NOT } \\
\text { TRUE }\end{array}$ & $49 \%$ & $35 \%$ & $16 \%$ \\
\hline 11 & $\begin{array}{l}\text { Investing in equity funds is riskier than a } \\
\text { bank deposit }\end{array}$ & TRUE & $58 \%$ & $11 \%$ & $31 \%$ \\
\hline 12 & $\begin{array}{l}\text { Out of two interest-bearing saving accounts } \\
\text { at an annual interest rate of } 4 \% \text { a monthly } \\
\text { rather than a quarterly capitalization of } \\
\text { interest is a better option }\end{array}$ & TRUE & $53 \%$ & $14 \%$ & $34 \%$ \\
\hline
\end{tabular}

Source: Own

Having analysed the data presented in Tab. 2 a conclusion can be drawn that the most problematic statement faced by young people was the one stating that: "A credit can be taken only in a bank". As many as $75 \%$ of the respondents marked an incorrect answer, whereas only $20 \%$ provided a correct one. Unfortunately it is confirmed by the fact that the majority of Poles identify bank credits with loans granted by institutions representing the shadow banking sector. Therefore, they remain unaware that the law dedicated to borrowers' rights protection, e.g. the Consumer Credit Act, does not refer to them. The results of responses given to the discussed statement, provided by particular groups of the surveyed young people, are presented in Figure 4. 


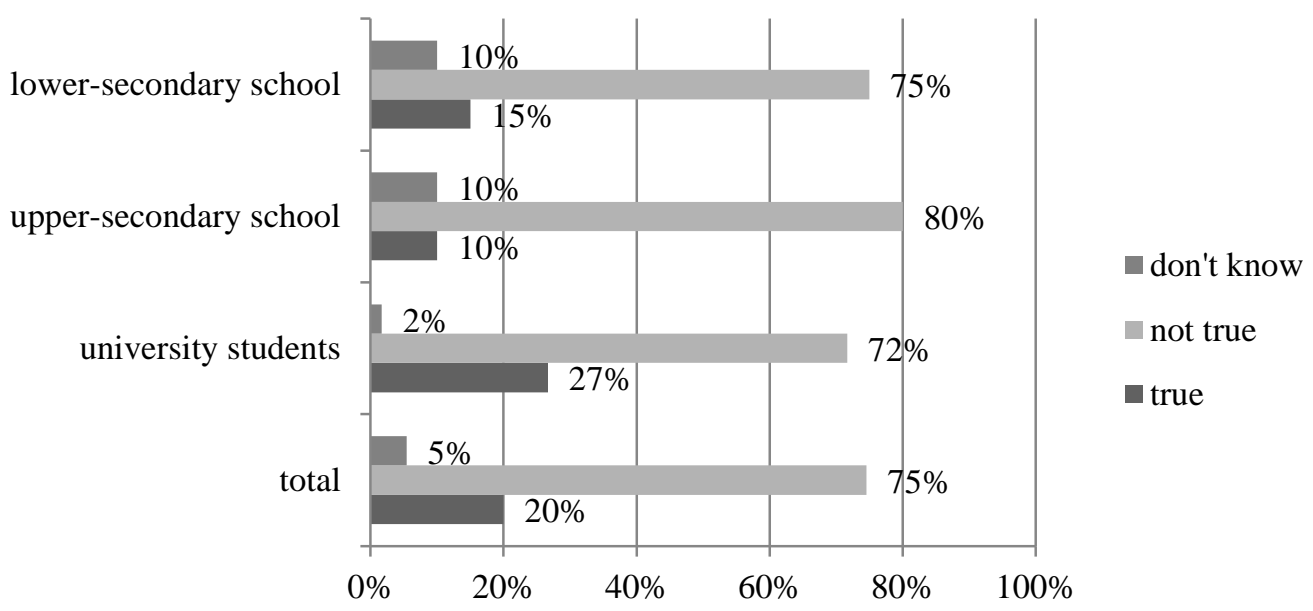

Source: Own

Fig. 4: The results of responses provided to the statement: "A credit can be taken only in a bank" in particular groups of young people

The analysis of Figure 4 confirms that among all analysed groups of young people the majority of correct responses to the statement that a credit can be taken only in a bank were provided by university students $-27 \%$. The fewest correct answers were given by students of upper-secondary - only $10 \%$ of them were aware that it is a bank only which can grant a credit. Such low percentage of correct answers can result from the fact that the majority of juniors aged 16-18 are still living with their parents and do not have the need to apply for a credit, hence they do not have a thorough knowledge in this matter. The misconception that loans may grant other institutions than the bank can be also caused by the growing popularity of shadow banking offering products commonly called "Payday Loans", although the lyrics are only loans, whose signing in shadow banking is much easier than in banks.

Attention is also an answer to the statement of youth: "Each bank charges a fee for keeping accounts". Almost $40 \%$ of surveyed young people found that the fee that gets every bank. It follows from the fact that a large percentage of young people do not know that many banks by creating products "tailor made" needs of young people does not levy a charge account, thus giving the young people a chance to managed their savings. The lack of sufficient knowledge on this subject testifies to the fact that the financial competence of young people is not sufficient to make rational financial decisions.

Apart from checking the theoretical knowledge presented by young people it was also important to find out whether they can apply it in practice. It was tested by asking for their reaction to the statement: "Kowalski who set up a deposit of PLN 50000 can lose the entire amount if his bank declares bankruptcy". (Bank Guarantee Fund extends its guarantee over the deposits up to EUR 100.000 per one depositor, i.e. about PLN 400.000). The responses given by the surveyed, divided into particular age groups, are presented in Figure 5. 


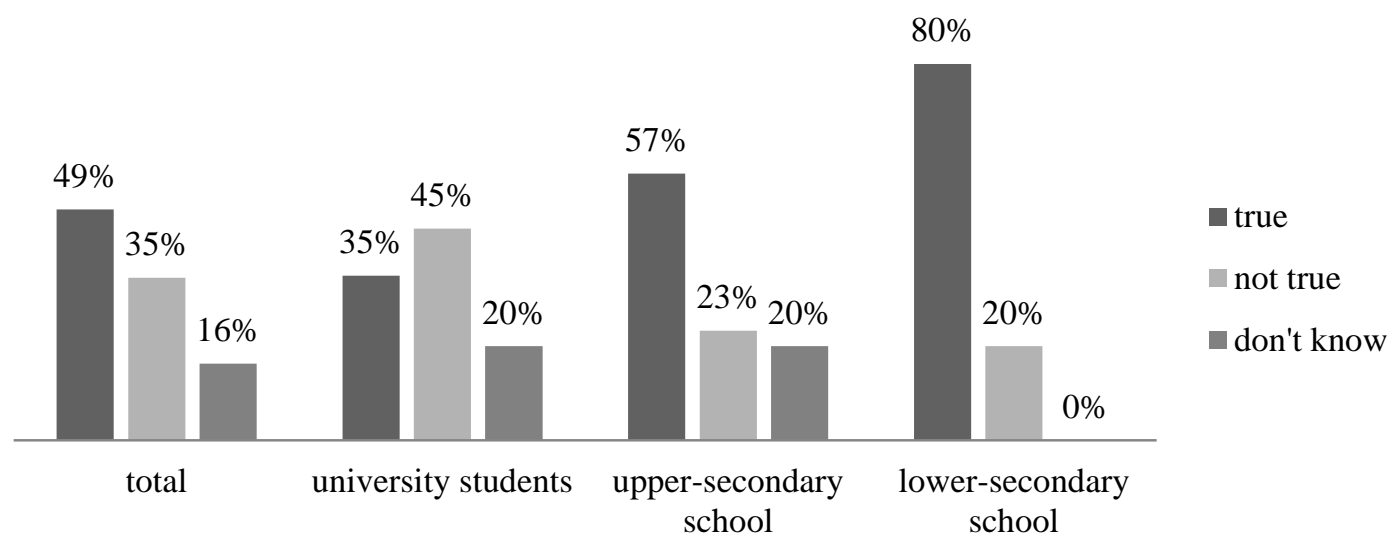

Source: Own

Fig. 5: The results of responses provided to the statement: "Kowalski who set up a deposit of PLN 50000 can lose the entire amount if his bank declares bankruptcy" in particular groups of young people

The analysis of data presented in Figure 5 illustrates that the largest number of incorrect responses to this question was given by students of lower-secondary school - as few as $20 \%$ of them knew the right answer and as many as $80 \%$ marked the wrong one. The highest percentage of correct responses $-45 \%$ was given by university students. However, having taken into account that as many as $77 \%$ of university students have their own bank account, the percentage of them answering correctly is not impressive and proves that the vast majority of them do not present an adequate knowledge about depositing money at a bank account. An extensive proportion of the surveyed respondents (as many as 16\%) did not know the answer to this question at all. It is clear from the answers given by young people, they do not know that the money that is collected on investments in domestic banks are protected by the Bank Guarantee Fund and if the Bank announce the bankruptcy, Fund will pay the money accumulated in the Bank within 20 days.

Practical financial literacy has been also tested by question 12: "Out of two interest-bearing saving accounts at an annual interest rate of $4 \%$ a monthly rather than a quarterly capitalization of interest is a better option." Answers given by young people are presented in Figure 6.

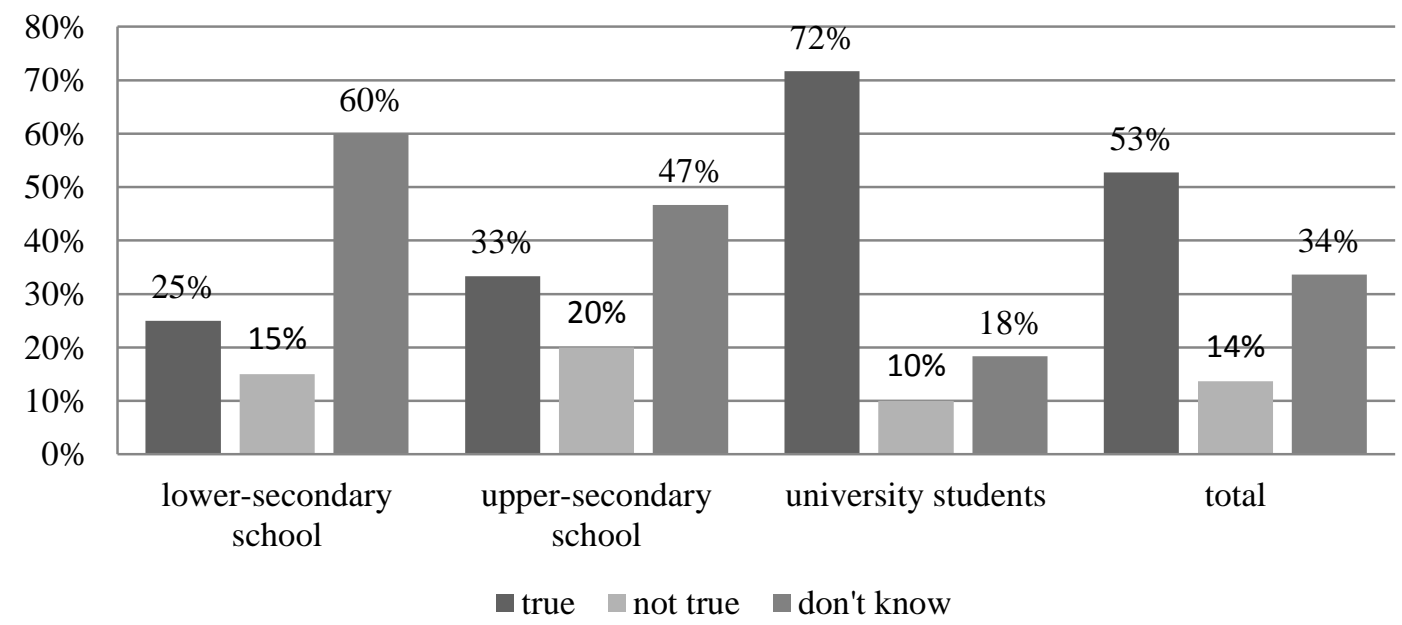

Source: Own

Fig. 6: The results of responses provided to the statement: "Out of two interest-bearing saving accounts at an annual interest rate of $4 \%$ a monthly rather than a quarterly capitalization of interest is a better option" 
The analysis of data presented in Figure 6 shows that $53 \%$ of the surveyed young people knows the correct answer to this statement. However, it should be noted that as many as 34\% of the respondents replied "don't know". Among those respondents is up to $60 \%$ students from lower-secondary school, $47 \%$ students from upper-secondary school. Lack of knowledge on this topic may result from the fact that, for example, in the lower-secondary school among people who do not know the answer to this statement $50 \%$ of them do not have a bank account. There is also the possibility that surveyed young people who replied "don't know", cannot indicate the differences between the quarterly and monthly capitalization of interest and therefore is not able to indicate which of the two savings accounts is a better option.

Subjective responses given by young people, in terms of their knowledge about financial issues from Figure 3, were compared against the answers provided by the surveyed respondents to the statements checking their objective level of financial competencies. The results of an objective level of such competencies are presented in Figure 7.

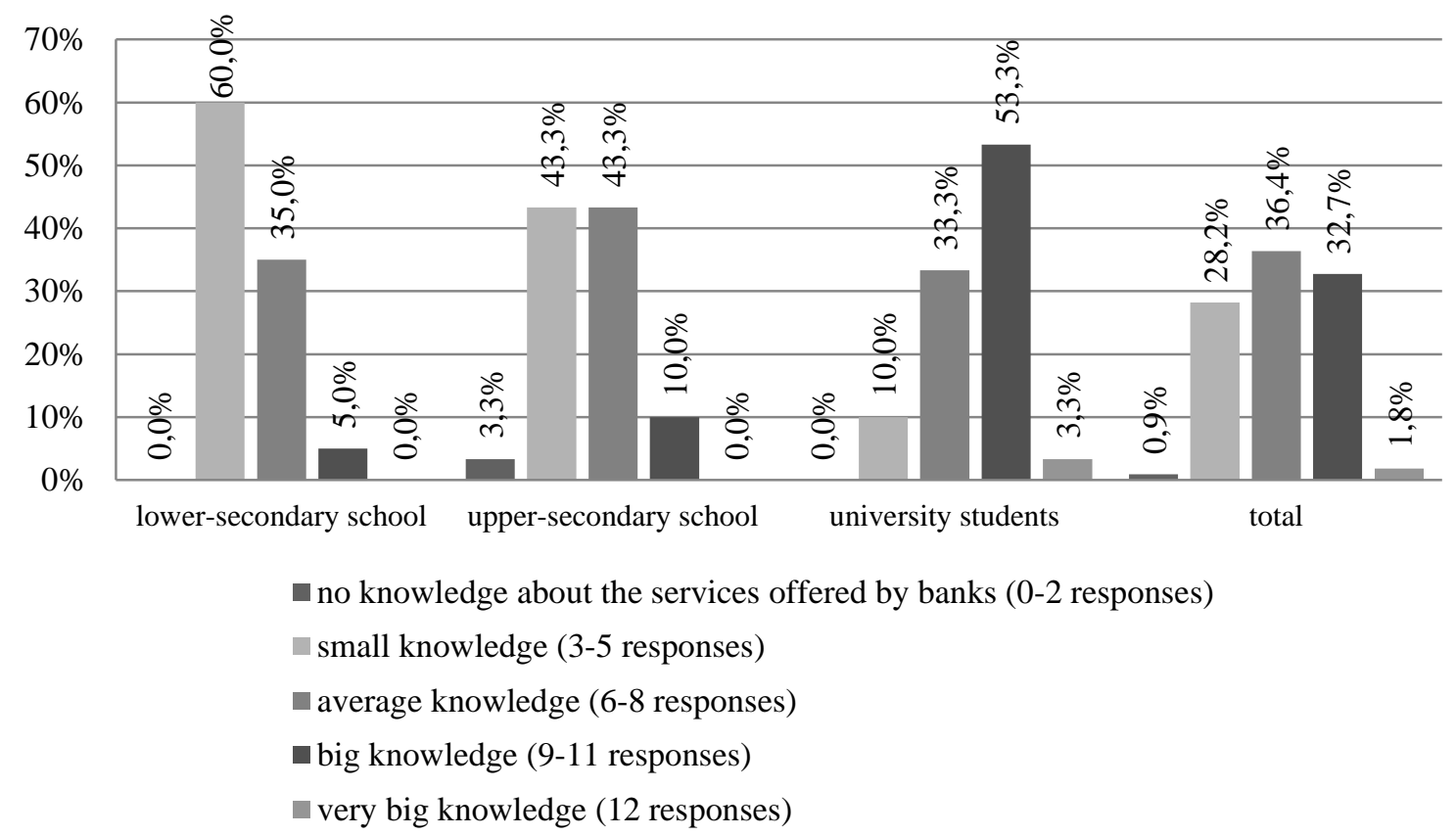

Source: Own

Fig. 7: An objective level of financial literacy determined based on the number of correct answers

The analysis of Figure 7 illustrates that only $1.8 \%$ of the surveyed young people present a very big knowledge about financial services. $32.7 \%$ have a big knowledge, whereas the largest percentage of the surveyed youth $(36.7 \%)$ present an average knowledge regarding the discussed subject matter. Small knowledge in finance is characteristic for $28.2 \%$ of the respondents. Having compared the results illustrated by Figure 7 against the data presented in Figure 3, identifying the subjective level of financial knowledge, a conclusion can be drawn that they remain quite similar. Both objective and subjective knowledge presented by the majority of young people persists on an average level. This shows that the financial knowledge of young people is not sufficient to make rational financial decisions. Insufficient financial knowledge and a low percentage of young people having a bank account allows to believe that if this condition not change, young people will be exposed to financial exclusion in the future.

The results of the conducted financial literacy study show that an average level of financial knowledge represented by young people requires implementing numerous education 
activities. They should be focused on extending both theoretical and practical knowledge of juniors explaining how the financial market functions.

\section{Selected educational activities improving financial literacy among young people}

In 2003 OECD initiated an international programme for financial education which consists in organizing extensive activities aimed at popularizing knowledge and creating positive habits among citizens resulting in proper decisions related to their personal finance management, as well as their ability to take advantage of their financial means according to their current and future needs. One of the after-effects of this programme was the document, published in 2005, which presents principles and good practices in the field of financial education (for more see [23, pp. 1-7]). Three years later the International Network on Finance Education (INFE) was established, which promotes and facilitates cooperation in financial education worldwide. This organization was bringing together over 200 institutions from 90 countries in 2012. Its activities focused on raising literacy regarding the vital role of financial education in fighting financial exclusion resulted in developing, in many countries, national strategies for financial education, among others in Austria (introduced in 2011), Brazil (2010), The Czech Republic (2010), Ghana (2009), India (2006, 2010), Japan (2005), Great Britain (2003), USA (2006, 2011) [10, p. 12].

Unfortunately so far (August 2015) such document has not been developed in Poland and thus clear educational goals have not been defined as yet. Moreover, the specific subjects to teach within the framework of financial education curricula have not been identified either. Diverse institutions have been attempting to carry out this task, starting from the Central Bank, through banks, insurance institutions, colleges, various foundations, associations, NGOs, even including municipalities. However, all these initiatives are not coordinated in any way at the national level, the obtained results are not monitored and the absence of empirical data prevents performing an overall analysis and assessment of their implementation effectiveness.

The next part of the study discusses selected nationwide educational programs will which facilitate knowledge advancement and skills improvement of the youth. Among them the following programs can be listed:

- "Everyday economics" - the programme aimed at upgrading economic knowledge among lower-secondary school students. As a result of their participation in this programme young people prepare themselves for making rational economic decisions, they learn to comprehend processes occurring in economy and also to manage properly the resources at their disposal on a daily basis. This programme implementation allows developing entrepreneurial attitudes among young people. The programme is carried out by the Foundation of Junior Entrepreneurship in cooperation with the National Bank of Poland. In 2013/2014 school year 105600 students and 2400 teachers from 1156 school took part in it $[9$, p. 13].

- "My finance" - financial education programme carried out in upper-secondary schools dedicated to preparing teenagers for rational management of their financial means. Owing to its wide range of impact this programme offers a response to public demand for financial education. Due to this initiative it is possible to educate the society and prepare it for more effective management of the resources at its disposal. Students participating in this programme:

$\circ$ acquire knowledge about investing in bonds and investment funds,

- learn about basic banking products, such as a credit or a deposit, 
- gain skills allowing for proper analysis of the consequences resulting from their financial decisions.

- This programme is carried out during a school year in 6 thematic modules covering e.g. such issues as investing or saving. In 2013 a special online platform was developed to offer interactive educational information for 4 out of 6 implemented thematic modules. Kronenberg Foundation and the National Bank of Poland are responsible for this programme's financing, whereas its implementation at schools remains the task of the Foundation of Junior Entrepreneurship. In 2013, the number of students who took part in this programme amounted to 129899 and the programme itself was executed by 1510 teachers at 956 schools all over Poland [8, p 19].

- "Task league"-the project carried out by the Foundation of Bank Zachodni WBK in cooperation with the Institute of Mathematics at the University of Warsaw addressed to students of primary, lower-secondary and upper-secondary schools. Every month during the entire school year students participating in this project attend a new series of mini lectures, which cover financial and economic issues, followed by solving problems online related to problems discussed during lectures. Their topics are adjusted to issues currently discussed both in Poland and in Europe. In 2013 such lectures covered, among others: tax reliefs, leasing, Euro currency, or setting up a business. In 2013 the foundation allocated the amount of over PLN 14000 to this project implementation [31, p. 4].

- "BAKCYL - Bankers for Financial Education of Young People" - the project was implemented to commemorate the 20th anniversary of Warsaw Institute of Banking. It takes the form of a long-term partnership involving institutions representing the banking sector to upgrade the level of knowledge among young people in the field of finance. In 2014, this projects was distinguished in the Competition of the World Leaders in Banking in terms of business corporate responsibility. Its objective is to support schools in extending young people's knowledge in the domain of finance to raise their awareness about participation in the contemporary world of finance. The programme is supposed to introduce juniors into the area of finance and teach them skills in taking advantage of financial services tailored specifically for them. During BAKCYL lessons the following topics are discussed:

- Your money - teaches juniors how to plan their budget, distinguish such terms as income and expenditure, as well as become aware of the advantages resulting from having savings,

O Borrow smartly - teaches the skill of rational borrowing, only for the stuff which is really indispensable, to become aware of the real costs involved in taking a credit and the need to repay it in the future, to learn how to use banking products safely,

- Finance for life - the theme allowing young people to comprehend the need for planning their financial resources at every stage of life, to identify the needs and benefits resulting from planning them.

- Smart investing - shows students the difference between saving and investing, explains the meaning of risk in banking to be fully aware of its existence.

- In 2014 the following banks acted as partners in this programme: Bank BGŻ, Bank Pekao, Bank Millennium, Deutsche Bank Polska, ING Bank Śląski, mBank, Raiffeisen Polbank and more. In 201431 schools took part in the programme in Mazowieckie, Łódzkie and Lubelskie regions, 206 lessons were taught in 67 classes [35, pp. 1-4]. 
The Internet portals also participate in educational activities carried out to upgrade young people's financial competencies, e.g. the Portal of Economic Education NBPortal, the mission of which is to disseminate knowledge about economy, market mechanisms, the functioning of banks and financial markets. It was established in 2004 as an initiative of the National Bank of Poland and since then it was visited by over 10 million people. The educational offer prepared within the framework of this programme responded to the needs of lower-secondary and upper-secondary school students, university students, as well as teachers contributing to the development of these 3 groups of young people. The application of interactive and multimedia tools allows young people to extend their knowledge of economic problems, and also facilitates informed participation in the financial sector. Juniors visiting this portal have a chance to read numerous articles about the financial system's functioning, play interesting educational games, do quizzes offering interesting knowledge about finance in a simple way [26]. In 2013 this portal was visited by 630,753 users [32, p. 71].

Attention should also be paid to a nationwide campaign held in Poland and entitled "A week for saving". It is a media enhanced campaign promoting the idea of saving money and rational finance management among the Polish population. The project is carried out by the Kronenberg Foundation at Citi Handlowy bank in cooperation with the THINK Foundation. This venture remains one of the few nationwide educational activities promoting saving and rational management of personal financial means. Its purpose is to make people, including juniors, aware that skilful finance management allows both protecting and multiplying the financial resources at one's disposal. The campaign focuses on promoting practical financial skills related to opening a bank account or personal finance planning. In 2013 the campaign covered 4870 participants by its direct activities. Within the framework of taken up actions upper-secondary school students participated in various debates and competitions $[8$, pp. 20 21].

It should be emphasized that the activities discussed in the hereby article are not the only initiatives aimed at the improvement of financial competencies among Polish young people. Moreover, the analysis of diverse source documents confirms that each year more and more such educational programmes are being offered.

\section{Conclusion}

The research conducted in a group of young people from Lower Silesia region proves that the level of financial literacy remains insufficient and similar to the subjective perceptions of the respondents. It confirms the thesis that both financial knowledge and skills should be taught since the earliest years. In relation to children it can take the form of economic socializing, whereas with reference to secondary school and university students economic education becomes vital, including the one executed by financial institutions. Economic socialization, in the opinion of Roland-Levy, refers to the so-called economics for unprofessional individuals, also referred to as naive economics [29, p. 277]. It allows learning about the value of money and the rules for one's own means management. It most frequently happens through observing adult behaviour and facilitates obtaining skills useful for independent life.

Economic socialization stands for constructing deep financial awareness, i.e. proper habits to be additionally developed in the process of education [6, p. 100]. The review of educational activities carried out in Poland and offered by financial institutions confirms that they perceive the need for upgrading financial literacy among young people. They are manifested by higher confidence in the financial system or the possibility to attract future clients originating from the educated group. Nevertheless, the scale of undertaken educational activities is far too small against the existing needs and characterized by randomness. 
Fighting financial illiteracy results in numerous advantages, not just for households or financial institutions, but also for the State [36, p. 7]. It allows, among others, to alleviate the effect of imperfect consumer legal protection and subsequently reduces the need for including the State in the financial market regulation. Financial education remains directly related to financial inclusion constituting the background of responsible finance, for more see Solarz (2013) [30, pp. 156-166].

\section{Literature}

[1] ATKINSON, A.; MESSY, F. A.: Measuring Financial Literacy: Results of the OECD / International Network on Financial Education (INFE) Pilot Study, OECD Working Papers on Finance, Insurance and Private Pensions. No. 15, OECD Publishing, 2012. DOI: $10.1787 / 20797117$

[2] AUSTRALIA AND NEW ZEALAND BANKING GROUP LIMITED: ANZ Survey of Adult Financial Literacy in Australia. [online]. (The Social Research Centre) ANZ Banking Group, Melbourne, 2008. [accessed 2015-04-30]. Available from WWW: http://ec.europa.eu/finance/finservices-retail/docs/capability/report_survey_en.pdf

[3] COMMISSION OF THE EUROPEAN COMMUNITIES: Communication from the commission - financial education. [online]. COM (2007), 808 final, Brussels, 2007. [accessed 2015-04-20]. Available from WWW: http://eur-lex.europa.eu/legalcontent/EN/TXT/PDF/?uri=CELEX:52007DC0808\&from=EN

[4] COMMISSION OF THE EUROPEAN COMMUNITIES: Green paper - promoting a European Framework for corporate social responsibility. [online] COM (2001), 366 final, Brussels, 2001. [accessed 2015-04-23]. Available from WWW: http://www.europarl.europa.eu/meetdocs/committees/deve/20020122/com\%282001\%29 366_en.pdf

[5] EUROPEAN COMMISSION: Financial services provision and prevention of financial exclusion. [online]. Brussels, 2008. [accessed 2015-04-15]. Available from WWW: http://ec.europa.eu/social/BlobServlet?docId=5092\&langId=en

[6] FLEJTERSKI, S.: Świadomość ekonomiczna i społeczna jako determinanta kondycji ekonomicznej gospodarstw domowych na tle badań (wtórnych i pierwotnych). In: Świecka, B. (ed.), Bankructwa gospodarstw domowych. Perspektywa ekonomiczna $i$ społeczna. Difin, Warszawa, 2008, pp. 92-143. ISBN 978-83-7251-918-4.

[7] FRAZER, H.; MARLIER, E.: In-Work Poverty and Labour Market. Segmentation in EU, Synthesis Report, Overview Based on The National Reports Prepared by The EU Network of Independent Experts on Social Inclusion. [online]. Brussels, 2010. [accessed 2015-04-25]. Available from http://ec.europa.eu/social/BlobServlet?docId=8992\&langId=en

[8] FUNDACJA KRONENBERGA PRZY CITI HANDLOWY: Raport Roczny z działań społecznych 2013. [online]. Warszawa, 2014. [accessed 2015-04-15]. Available from WWW: http://www.citibank.pl/poland/kronenberg/polish/files/raport_roczny fk_2013.pdf

[9] FUNDACJA MŁODZIEŻOWEJ PRZEDSIĘBIORCZOŚCI: Raport roczny 2013. [online]. Warszawa, 2014. [accessed 2015-04-15]. Available from WWW: http://www.junior.org.pl/upload/File/RaportFundacji2013.pdf 
[10] GRIFONI, A.; MESSY, F. A.: Current Status of National Strategies for Financial Education. A Comparative Analysis and Relevant Practices. [online]. OECD Working Papers on Finance, Insurance and Private Pensions 16/2012. [accessed 2015-09-03]. Available from WW: http://www.oecdilibrary.org/docserver/download/5k9bcwct7xmn.pdf?expires $=1441307913 \&$ id=id\&accn ame $=$ guest $\&$ checksum $=65$ D5AA5BD31D3CD526A5ED62DC0CC456

[11] HABSCHICK, M.; SEIDL, B.; EVERS J.: Survey of Financial Literacy Schemes in The EU 27, VT Markt/2006/26H - Final Report. [online]. Hamburg, 2007. [accessed 201505-01]. Available from WWW: http://ec.europa.eu/finance/finservicesretail/docs/capability/report_survey_en.pdf

[12] HASTINGS, J. S.; MITCHELL, O. S.: How financial literacy and impatience shape retirement wealth and investment behaviors. [online]. National Bureau of Economic Research Working Papers 16740. MA: Cambridge, 2001. [accessed 2015-05-03]. Available from WWW: http://www.nber.org/papers/w16740.pdf

[13] HM TREASURY: Financial Capability: the Government's long-term approach. Crown, London, 2007. ISBN 978-1-84532-247-2.

[14] INTERNATIONAL NETWORK ON FINANCIAL EDUCATION (INFE): Measuring Financial Literacy: Questionnaire and Guidance Notes for Conducting an Internationally Comparable Survey of Financial Literacy. [online]. OECD/INFE, Paris, 2011. [accessed 2015-05-01]. Available from WWW: http://www.oecd.org/finance/financialeducation/49319977.pdf

[15] IWANICZ-DROZDOWSKA, M.: Edukacja i świadomość finansowa. Doświadczenia i perspektywy. Oficyna Wydawnicza SGH w Warszawie, Warszawa 2011. ISBN 978-837378-622-6.

[16] LUSARDI, A.; MITCHELL, O. S.: Financial literacy and planning: Implications for retirement wellbeing. [online]. Pension Research Council Working Paper. No. 1. The Wharton School, The University of Pennsylvania, 2006. [accessed 2015-05-03]. Available from WWW: www.dartmouth.edu/ alusardi/Papers/FinancialLiteracy.pdf

[17] LUSARDI, A.; MITCHELL, O. S.: The economic importance of financial literacy theory and evidence. [online]. National Bureau of Economic Research Working Paper 18952, MA: Cambridge, 2013. [accessed 2015-05-04]. Available from WWW: http://www.nber.org/papers/w18952.pdf

[18] LUSARDI, A.; TUFANO, P.: Debt Literacy, Financial Experiences, and Overindebtedness. [online]. National Bureau of Economic Research Working Paper 14808, MA: Cambridge, 2009. [accessed 2015-05-03]. Available from WWW: http://www.nber.org/papers/w14808.pdf

[19] MAJEWSKI B.: Badanie świadomości i podstaw wiedzy ekonomicznej wśród uczestników programów edukacyjnych skierowanych do najmłodszych. E-mentor. 2010, No. 2 (34), pp. 22-29. ISSN 1731-6758.

[20] MATUL, M.; PAWLAK, K.; FAŁKOWSKI, J.: Priorytety wzmacniania edukacji finansowej wśród ubogich rodzin w Polsce. [online]. Warszawa, 2004. [accessed 201504-29]. Available from WWW: http://www.edufin.pl/images/pdf/dok4.pdf

[21] OECD: Financial Literacy and consumer Protection. Overlooked Aspects of the Crisis. [online]. OECD Publishing, 2009. [accessed 2015-01-05]. Available from WWW: http://www.oecd.org/finance/financial-markets/43138294.pdf 
[22] OECD: Improving financial literacy: analysis of issues and policies. [online]. OECD Publishing, 2005. [accessed 2015-05-01]. Available from WWW: http://www.oecdilibrary.org/docserver/download/2105101e.pdf?expires=1430429648\&id=id\&accname= ocid53014339\&checksum=A1FC7C81B5F5F2DB0F31F832A2AC10EA

[23] OECD: PISA 2012 Assessment and Analytical Framework: Mathematics, Reading, Science, Problem Solving and Financial Literacy. [online]. OECD Publishing, 2013. [accessed 2015-04-30]. Available from http://www.oecd.org/pisa/pisaproducts/PISA\%202012\%20framework\%20ebook_final.pdf

[24] OECD: The Recommendation on Principles and Good Practices for Financial Education and Awareness. [online]. OECD Publishing, Paris 2005. [accessed 2015-0903]. Available from WWW: http://www.oecd.org/finance/financialeducation/35108560.pdf

[25] Opinion of the European Economic and Social Committee on "Credit and social exclusion in an affluent society". Official Journal of the European Union. 2008/C $44 / 19$.

[26] Portal Edukacji Ekonomicznej. [online]. Narodowy Bank Polski, Warszawa, 2015. [accessed 2015-04-24]. Available from WWW: https://www.nbportal.pl/o-nbportal.pl

[27] PRI (POLICY RESEARCH INITIATIVE): Why Financial Capability Matters, Synthesis Report prepared by Social and Enterprise Development Innovations for the PRI Project „New Approaches for Addressing Poverty and Exclusion”, Report on „Canadians and Their Money: A National Symposium on Financial Capability”. Financial Consumer Agency of Canada, Ottawa, 2005. ISBN 0-662-49129-7.

[28] Raport Fundacji Kronenberga przy Citi Handlowy, Stan wiedzy finansowej Polaków (2009). [online]. Dom Badawczy Maison, Warszawa, 2009. [accessed 2015-04-29]. Available from WW: http://www.citibank.pl/poland/kronenberg/polish/files/fk_badania_01.pdf

[29] ROLAND-LEVY, C.: W jaki sposób nabywamy pojęcia i wartości ekonomiczne. In: Tyszka, T. (ed.), Psychologia Ekonomiczna. Gdańskie Wydawnictwo Psychologiczne, Gdańsk 2004, pp. 277-299. ISBN 83-89120-90-9.

[30] SOLARZ, M.: Financial capability development as the responsible finance instrument counteracting financial exclusion. In: Borys, G.; Solarz, M. (eds.), Finance and Accountancy for Sustainable Development - Sustainable Finance. Research Papers of the Wroclaw University of Economics No. 302, Publishing House of Wroclaw University of Economics, Wroclaw, 2013, pp. 156-166. ISSN 1899-3192.

[31] Sprawozdanie merytoryczne z działalności za rok 2013 Fundacji Banku Zachodniego WBK S.A.. [online]. Warszawa, 2014 [accessed 2015-04-24]. Available from WWW: http://fundacja.bzwbk.pl/content/uploads/2014/07/Sprawozdanie-merytoryczne-za-rok2013.pdf

[32] Sprawozdanie z działalności NBP w 2013 roku. [online]. Narodowy Bank Polski, Warszawa, 2014. [accessed 2015-05-01]. Available from WWW: https://www.nbp.pl/publikacje/sprawozdanie_z_dzialalnosci_nbp/sprawozdanie_2013.pdf 
[33] THE WORLD BANK: Global Financial Development Report 2014: Financial Inclusion. [online]. Washington, DC: World Bank, 2014. [accessed 2015-01-05]. Available from WWW: http://siteresources.worldbank.org/EXTGLOBALFINREPORT/Resources/88160961361888425203/9062080-1364927957721/GFDR-2014_Complete_Report.pdf

[34] VAN ROOIJ, M.; LUSARDI, A.; ALESSIE, R.: Financial literacy and stock market participation. [online]. NATIONAL BUREAU OF ECONOMIC RESEARCH Working Papers No. 13565, MA: Cambridge, 2007. [accessed 2015-05-03]. Available from WWW: http://www.nber.org/papers/w13565.pdf

[35] WARSZAWSKI INSTYTUT BANKOWOŚCI: Broszura podsumowujaca projekt BAKCYL 2014. [online]. Warszawa, 2014. [accessed 2015-04-24]. Available from WWW: http://bakcyl.wib.org.pl/sukcesy-bakcyla

[36] WILLIAMS, O. J.; SATCHELL, S. E.: Social welfare issues of financial literacy and their implications for regulation. Journal of Regulatory Economics. 2010, Vol. 40, No. 1, pp. 1-40. DOI: $10.1007 / \mathrm{s} 11149-011-9151-6$

[37] WILLIS, L.E.: The Financial Education Fallacy. American Economic Review. 2011, Vol. 101, No. 3, pp. 429-434. DOI: 10.1257/aer.101.3.429

Justyna Kurczewska, B.A.; Małgorzata Solarz, Ph.D. 


\section{VYHODNOCENÍ A ZDOKONALOVÁNÍ FINANČNÍ GRAMOTNOSTI MLÁDEŽE}

Finanční znalosti a dovednosti jsou podmínkou správného nakládání s finančními prostředky domácnosti, chrání před finanční exkluzí. Cílem tohoto př́íspěvku je vyhodnocení míry finanční gramotnosti mládeže a prezentace vybraných vzdělávacích aktivit zaměřených na mladé Poláky, které mají zdokonalit jejich finanční znalosti a dovednosti. Dosavadní průzkumy a výsledky uskutečněného dotazníkového šetření dokládají, že finanční gramotnost mládeže z Dolního Slezska je nepostačující. Polské finanční instituce vnímají potřebu vyvíjení různých mechanismů pro zvýšení finančního povědomí mladých lidí, nicméně rozsah uskutečňovaných vzdělávacích aktivit je př́liš malý vzhledem k potřebám, a je také náhodný.

\section{BEWERTUNG UND AUSBILDUNG FINANZIELLER FÄHIGKEITEN DER JUGEND}

Finanzielle Kenntnisse und Fertigkeiten bilden die Bedingung für eine ordnungsgemäße Verwaltung des persönlichen Haushaltsgeldes und schützen gegen finanzielle Ausgrenzung. Das Ziel des Beitrags ist es, das Niveau der finanziellen Kompetenz der Jugendlichen einzuschätzen und die - an junge Polen adressierten - ausgewählten Bildungsaktivitäten vorzustellen, die ihr finanzielles Wissen und Können vervollkommnen sollen. Eine Überprüfung der bisherigen Forschung und die Ergebnisse der durchgeführten Umfrage haben bewiesen, dass die finanziellen Fähigkeiten der Jugend aus Niederschlesien nicht ausreichend sind. Die polnischen Finanzinstitute erkennen die Notwendigkeit, artverschiedene Mechanismen, die das finanzielle Bewusstsein junger Leute steigern, anzunehmen. Nichtsdestotrotz ist aber das Ausmaß der laufenden Bildungsaktivitäten in Bezug auf die Bedürfnisse zu klein und es zeichnet sich durch Zufälligkeit aus.

\section{DIAGNOZA ORAZ DOSKONALENIE KOMPETENCJI FINANSOWYCH MŁODZIEŻY}

Posiadanie wiedzy i umiejętności finansowych stanowi warunek właściwego zarządzania finansami osobistymi gospodarstwa domowego, chroni przed wykluczeniem finansowym. Celem artykułu jest zdiagnozowanie poziomu wiedzy finansowej młodzieży i przedstawienie wybranych działań edukacyjnych skierowanych do młodych Polaków, które mają doskonalić ich wiedzę i umiejętności finansowe. Przegląd dotychczasowych badań oraz wyniki przeprowadzonej ankiety dowodzą, że wiedza finansowa młodzieży Dolnego Śląska jest niewystarczająca. Polskie instytucje finansowe dostrzegają potrzebę podejmowanie różnego rodzaju mechanizmów podnoszenia świadomości finansowej młodych ludzi, niemniej jednak skala realizowanych działań edukacyjnych jest zbyt mała do potrzeb i cechuje ją przypadkowość. 